http://journal.unhas.ac.id

\title{
Aktivitas Imunoglobin Mencit Jantan Pasca Pemberian Isolat Probiotik Dari Susu Kerbau
}

\author{
Zaraswati Dwyana $^{1}$, Syafaraenan ${ }^{1}$, Sartini $^{2}$, Jepi Kendek Tasik ${ }^{1}$ \\ ${ }^{I}$ Departemen Biologi FMIPA Universitas Hasanuddin \\ ${ }^{2}$ Fakultas Farmasi Universitas Hasanuddin \\ email: zaraswatidwyana@gmail.com
}

\begin{abstract}
Abstrak
Probiotik adalah suplemen makanan yang mengandung mikroorganisme hidup, dikonsumsi dengan tujuan memberi banyak manfaat untuk kesehatan manusia. Telah dilakukan penelitian efek bakteri probiotik yang berasal dari susu kerbau terhadap aktivitas imunoglobulin. Tujuan dari penelitian ini adalah untuk mengetahui efek bakteri probiotik yang sebagai imunomodulator, terhadap aktivitas imunoglobulin. Bakteri probiotik yang digunakan yaitu isolat susu kerbau, diberikan secara peroral sebanyak 1 ml/30gBB mencit selama sepuluh hari. Kemudian setiap hewan diimunisasi dengan antigen sel darah merah domba (SDMD) $2 \%$ v/v secara intraperitoneal sebanyak 1 ml/30g BB mencit. Pengamatan aktivitas Imunoglobulin dilakukan pada hari kesebelas dengan menggunakan metode hemaglutinasi titer antibodi. Hasil penelitian adalah bakteri probiotik dari susu kerbau dapat meningkatkan aktivitas imunoglobulin lebih tinggi dari kelompok kontrol negatif (NaCMC 1\%). Hasil terbaik peningkatan aktivitas Imunoglobulin adalah isolat bakteri probiotik susu kerbau dengan hasil yang sangat signifikan dibandingkan dengan control negatif (NaCMC 1\%).
\end{abstract}

Kata kunci : Imunoglobulin , probiotik, susu kerbau

\section{PENDAHULUAN}

Bakteri probiotik tertentu dapat memperkuat sistem imun. Termasuk mikroorganisme yang bila dikonsumsi dalam jumlah tertentu bermanfaat bagi kesehatan. Beberapa manfaat yang menunjukkan efek kesehatan dengan pemanfaatan probiotik yaitu mengurangi terjadinya infeksi kuman, mengurangi gejala-gejala alergi, menghilangkan konstipasi, menghilangkan sindrom terjadinya iritasi pada pencernaan, bermanfaat pada metabolisme mineral, terutama kekuatan dan stabilitas tulang, pencegahan kanker, mengurangi kolesterol dan konsentrasi plasma triasilgliserol. Salah satu kelompok bakteri probiotik yang paling utama adalah bakteri asam laktat. Bakteri asam laktat meningkatkan fungsi sistem kekebalan tubuh pada tingkat usus dan sistemik. Pada manusia, bakteri asam laktat dimanfaatkan untuk meningkatkan limfosit B atau sel B yang mampu melawan benda asing, aktivitas fagositosis yang membantu untuk menghancurkan benda asing, mensekresikan sel yang menghasilkan IgA, IgG dan IgM yang akan meningkatkan aktivitas antibodi, dan meningkatkan $\gamma$-interferon yang membantu melawan penyakit sel darah putih. Probiotik juga memiliki 
kemampuan sebagai aktivator yang kuat untuk sistem imun innate karena mempunyai molekul yang spesifik tersebut, yang dikenal sebagai pathogen associated molecular patterns (PAMPs) (Çaglar et al., 2005 dan Wiwi, 2011).

Probiotik dapat diperoleh dari berbagai sumber terutama pada minuman dan makanan fermentasi dan selain itu dapat juga ditemukan pada susu dan produk olahannya seperti dangke. Oleh Dwyana, Z (2004) telah menemukan isolat bakteri asam laktat yang berasal dari kerbau dan diketahui mempunyai potensi sebagai penghasil antimikroba terhadap beberapa bakteri patogen.

\section{METODE PENELITIAN}

\section{Prosedur Kerja}

\section{Peremajaan Bakteri Probiotik}

Isolat bakteri probiotik dari susu kerbau di ambil 2 ose kemudian diinokulasi kedalam medium MRSB yang telah di buat sebanyak $5 \mathrm{ml}$.Setelah itu didiamkan di dalam inkubator selama 18 jam. Selanjutnya diambil sebanyak $5 \mathrm{ml}$ isolat bakteri probiotik kemudian diinokulasikan kedalam medium MRSB $45 \mathrm{ml}$ selanjutnya didiamkan kedalam inkubator selama 18 jam pada suhu $37^{\circ} \mathrm{C}$. Isolat bakteri probiotik yang telah diremajakan kemudian di pindahkan ke dalam medium MRSB yang telah di buat sebanyak $450 \mathrm{ml}$ dan di inkubasi selama 18 jam pada suhu $37^{\circ} \mathrm{C}$.

\section{Pengambilan Bakteri Probiotik dari Media MRSB}

Isolat bakteri dalam medium MRSB tersebut kemudian di sentrifugasi dengan kecepatan 3000 rpm selama 30 menit untuk memperoleh bakteri probiotiknya. Kemudian supernatan cairan MRSB pada lapisan atas di buang, sehingga yang tertinggal hanya endapannya. Endapan tersebut ditambahkan $5 \mathrm{ml} \mathrm{NaCl}$ fisiologis, disentrifugasi kembali dengan kecepatan $3000 \mathrm{rpm}$ selama 30 menit dan supernatan $\mathrm{NaCl}$ pada lapisan atas dibuang sehingga yang tertinggal hanya endapannya saja. Setelah itu endapan bakteri probiotik yang di dapatkan ditambahkan dengan malto dextrin sebanyak 5 gram. Sampel bakteri probiotik kemudian ditimbang beratnya dan dikurangkan dengan berat malto dextrin. Penambahan maltodextrin sebagai bahan prebiotik untuk membantu mengencerkan sel probiotik sesuai dengan jumlah sel yang diinginkan.

\section{Penentuan Konsentrasi Isolat Bakteri Probiotik}

Isolat bakteri kering yang didapatkan, ditimbang sebanyak 1 gram dan diencerkan dari $10^{-1}$ sampai $10^{-10}$ dengan menggunakan medium MRSA dan ditambahkan $\mathrm{CaCO}_{3}$. Kemudian isolat dengan pengenceran $10^{-7}$ sampai $10^{-10}$ di inkubasi selama 24 jam dan dihitung jumlah pertumbuhan bakterinya dengan metode ALT (angka lempeng total). Hasil perhitungan tersebut yang akan menentukan hasil pengenceran yang akan diberikan secara oral ke mencit.

\section{Pengujian Aktivitas Imunoglobulin Pada Hewan Uji}

\section{Pembuatan Phosphat Buffered Saline (PBS)}

Phosphat Buffered Saline (PBS) dibuat dengan cara mencampurkan larutan I yaitu larutan $\mathrm{NaH}_{2} \mathrm{PO}_{4} \cdot \mathrm{H}_{2} \mathrm{O} 1,3 \mathrm{~g} / \mathrm{l}$ dan $\mathrm{NaCl} 8,3 \mathrm{~g} / \mathrm{l}$ sebanyak $280 \mathrm{ml}$ dengan larutan II yaitu larutan $\mathrm{NaH}_{2} \mathrm{PO}_{4}$ 1,42 $\mathrm{g} / \mathrm{l}$ dan $\mathrm{NaCl}$ 8,5 g/l sebanyak $720 \mathrm{ml}$ sampai diperoleh PBS dengan $\mathrm{pH}$ 7,2.

\section{Pembuatan Suspensi Sel Darah Merah Domba (SDMD) 2\%}

Sebanyak $2 \mathrm{ml}$ darah domba ditampung dalam tabung yang bersih dan telah dikeringkan yang berisi dengan $1 \mathrm{mg}$ EDTA yang berfungsi sebagai antikoagulan. Kemudian disentrifugasi dengan kecepatan $1500 \mathrm{rpm}$ untuk memisahkan sel darah merah domba (SDMD) dari plasmanya. Sel darah merah domba yang didapatkan dicuci dengan penambahan sejumlah besar Phosphat Buffered Saline 
(PBS) dalam tabung, lalu tabung tersebut dibolak-balik beberapa kali, setelah itu disentrifugasi kembali. Pencucian dilakukan paling sedikit 3 kali. Setelah disentrifugasi, PBS dikeluarkan sehingga yang tertinggal adalah SDMD 100\%, lalu ditambahkan lagi PBS dengan jumlah yang sama hingga diperoleh suspensi SDMD 50\%. Sebanyak 0,4 ml SDMD 50\% diencerkan dengan 9,6 ml PBS hingga diperoleh suspensi antigen (SDMD 2\% v/v).

\section{Pemilihan dan Penyiapan Hewan Uji}

Hewan uji yang digunakan adalah mencit jantan Mus musculus yang sehat dengan bobot badan 20-30 gram, sebanyak 10 ekor mencit yang dibagi berdasarkan perlakuan dan dinyatakan telah teracak dengan baik jika bobot badan tiap mencit tidak berbeda nyata.

\section{Perlakuan Terhadap Hewan Uji}

Pada perlakuan ini, mula-mula mencit jantan diimunisasi dengan $1 \mathrm{ml}$ suspensi sel merah darah domba $2 \%$ secara intraperitoneal. Untuk perlakuan isolat bakteri probiotik setelah diimunisasi dengan suspensi sel darah merah domba $2 \%$ dilarutkan dengan $\mathrm{NaCMC}$ sebanyak dengan faktor konversi dosis mencit dengan volume $1 \mathrm{ml} / 25 \mathrm{~g}$ bobot badan secara oral setiap hari selama 10 hari. Pada hari ke sebelas, darah mencit jantan diambil secara intrakardiak untuk mengetahui aktivitas imunoglobulin. Perlakuan yang sama dalam penelitian ini juga diberikan pada kontrol larutan NaCMC sebanyak $1 \mathrm{ml} / 25 \mathrm{~g}$ bobot badan secara oral setiap hari selama 10 hari.

\section{Pengambilan Sampel Darah Hewan Uji}

Sampel darah hewan uji diambil secara intrakardiak pada hari kesebelas setelah imunisasi dan diletakkan pada suhu kamar selama 1-2 jam hingga darah tersebut membeku/menggumpal lalu diambil serumnya (supernatan) dengan cara disentrifuge selama 10 menit dengan kecepatan $3000 \mathrm{rpm}$.

\section{Uji Hemaglutinasi}

Serum yang diperoleh lalu di encerkan secara "double dilution" dengan phosphat Bufferred Saline (PSB) dengan perbandingan 1/4, 1/8, 1/16, 1/32, 1/64, 1/128, 1/256, dan 1/ 512. Dari masingmasing perbandingan ini di pipet sebanyak $50 \mu 1$ dan diletakkan pada 8 sumur piring mikrotiter (well plate 96) isolat bakteri probiotik dari susu kerbau dan kontrol NaCMC. Setelah itu, masing-masing ditambahkan 50 ul suspensi sel darah merah domba $2 \%$ pada setiap sumur dan digoyang-goyang selama 5 menit agar homogen. Selanjutnya di inkubasi pada suhu $37^{\circ} \mathrm{C}$ selama 60 menit dan didiamkan pada suhu kamar. Setelah itu dilakukan pengamatan pengenceran tertinggi dari setiap serum darah mencit jantan yang masi dapat mengaglutinasi sel darah merah domba.

\section{HASIL DAN PEMBAHASAN}

Data uji aktivitas imunoglobulin setelah pemberian isolat bakteri probiotik dari sampel Susu Kerbau dan kontrol NaCMC, berdasarkan titer imunoglobulin pada mencit jantan setelah diberikan SDMD $2 \% \mathrm{v} / \mathrm{v}$ adalah sebagai berikut : 
Tabel 1. Data Titer Imunoglobulin sesuai bentuk sumur mikrotiter (well plate) setelah pemberian isolat bakteri probiotik

\begin{tabular}{|c|c|c|c|c|c|c|}
\hline \multirow{2}{*}{$\begin{array}{c}\text { Pengenceran } \\
\text { Pada Sumur } \\
\begin{array}{c}\text { Mikrotiter } \\
\text { (Well Plate) }\end{array}\end{array}$} & \multicolumn{6}{|c|}{ Jenis Perlakuan } \\
\cline { 2 - 7 } & 1 & 2 & 3 & 1 & 2 & 3 \\
\hline $1 / 4$ & - & + & + & + & + & + \\
\hline $1 / 8$ & - & + & + & + & + & + \\
\hline $1 / 16$ & - & + & + & + & + & + \\
\hline $1 / 32$ & - & + & + & + & + & + \\
\hline $1 / 64$ & - & + & + & + & + & + \\
\hline $1 / 128$ & - & + & - & - & + & + \\
\hline $1 / 256$ & - & - & - & - & - & - \\
\hline $1 / 512$ & - & - & - & - & - & - \\
\hline
\end{tabular}

Keterangan : • Hasil $(+)$ menunjukkan pengenceran tertinggi yang masih dapat mengaglutinasikan antigen

- Hasil (-) menunjukkan pengenceran tertinggi yang tidak dapat mengaglutinasikan antigen (terdapat endapan)

Data uji aktivitas imunoglobulin setelah pemberian isolat bakteri probiotik dari sampel Susu Kerbau dan kontrol NaCMC, berdasarkan titer imunoglobulin pada mencit jantan setelah diberikan SDMD $2 \% \mathrm{v} / \mathrm{v}$ adalah sebagai berikut :

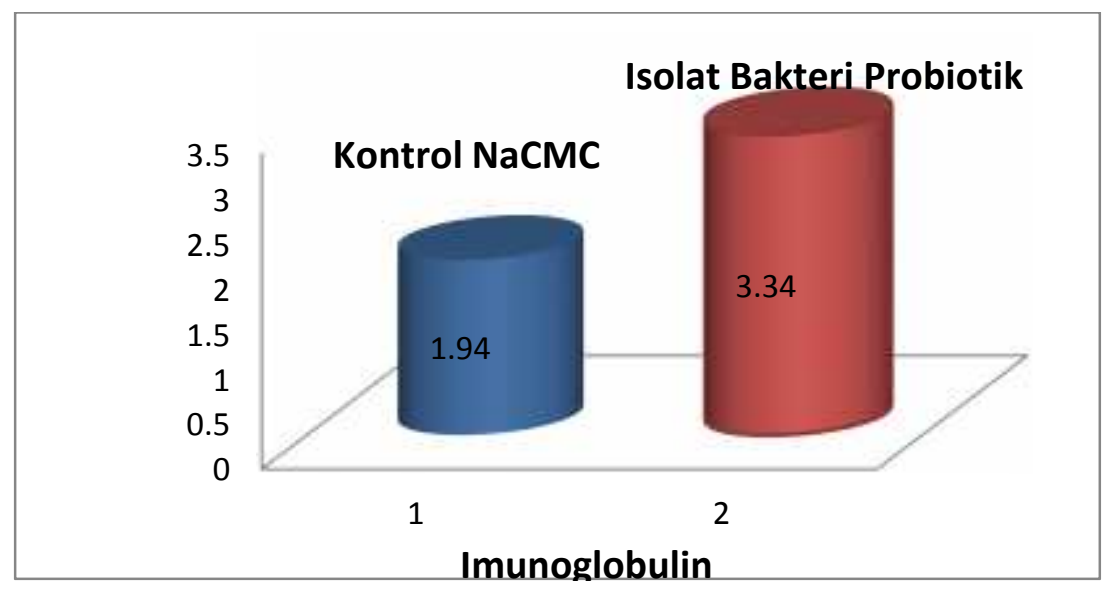

Gambar 1. Data Tliter Tertinggi imunoglobulin berdasarkan Histogram Setelah Ditransformasi dengan rumus :2 $\log ($ titer $)]+1$

Peningkatan aktivitas imunoglobulin lebih tinggi pada kelompok perlakuan yang diberikan isolat probiotik susu kerbau jika dibandingkan dengan kontrol negatif yang hanya diberikan NaCMC $1 \%$, dan diperoleh hasil bahwa peningkatan imunoglobulin lebih tinggi pada isolat probiotik susu kerbau. Hal ini sesuai dengan penelitian yang telah dilakukan sebelumnya oleh Moller C (2004) menyatakan bahwa bakteri probiotik dapat memperkuat sistem imun karena adanya bantuan mukus. Melekatnya probiotik pada mukus ini ternyata diakibatkan oleh suatu zat protein yang dimiliki oleh probiotik tersebut. Zat tersebut dinamakan "mucus-binding protein" (protein pengikat mukus), yang ternyata dijumpai dalam jumlah yang lebih banyak pada bakteri penghasil asam laktat, dengan adanya protein ini maka bakteri probiotik dapat menempel pada mukus saluran cerna dan melakukan interaksi 
dengan host. Peneliti ini juga menemukan bahwa ternyata "mucus-binding protein" mengenal protein imunoglobulin manusia yang merupakan bagian dari sistem imun, dan hasil penelitian yang sama dilakukan oleh Juge ,N (2000) dari Institute of Food Research berhasil mengungkapkan cara menempelnya suatu probiotik dalam saluran pencernaan, dari temuan ini juga dapat menjelaskan mengapa tidak semua bakteri dapat digunakan sebagai probiotik. Usus merupakan organ dengan sitem imun terluas di tubuh, sel-sel yang menyusun usus dilindungi oleh lapisan pelindung mukus yang secara terus-menerus mengalami proses regenerasi. Selain melindungi, ternyata mukus ini juga memberikan keuntungan bagi bakteri probiotik yaitu menjadi media melekatnya probiotik di dinding usus (Safitri S,2009). Melekatnya probiotik pada mukus ini ternyata diakibatkan oleh suatu zat protein yang dimiliki oleh probiotik tersebut, dari hasil penelitian diselidiki lebih jauh pada probiotik Lactobacillus reuteri. Zat tersebut dinamakan mucus-binding protein (protein pengikat mukus), yang ternyata dijumpai dalam jumlah yang lebih banyak pada bakteri penghasil asam laktat, dengan adanya protein ini maka bakteri probiotik dapat menempel pada mukus saluran cerna dan melakukan interaksi dengan host. Peneliti juga menemukan bahwa ternyata mucus-binding protein ini juga mengenal protein imunoglobulin yang merupakan bagian dari sistem imun. oleh karena itu peranan mucus binding protein ini tampaknya akan lebih luas lagi selain sebagai media perlekatan probiotik pada dinding saluran cerna. Dari fakta temuan yang telah dijabarkan di atas, jelas bahwa bakteri yang diplih sebagai probiotik sebaiknya bakteri yang mampu menghasilkan mucus-binding protein, agar bakteri dapat survive dan bertahan untuk meningkatkan populasi dalam saluran cerna.

Pada pengamatan aktivitas imunoglobulin menunjukkan adanya perbedaan yang sangat signifikan antara kelompok kontrol negatif terhadap kelompok perlakuan pemberian isolat bakteri probiotik susu kerbau. Dari hasil ini berarti terjadi peningkatan aktivitas imunoglobulin dengan pemberian isolat bakteri probiotik susu kerbau jika dibandingkan dengan kontrol negatif NaCMC.

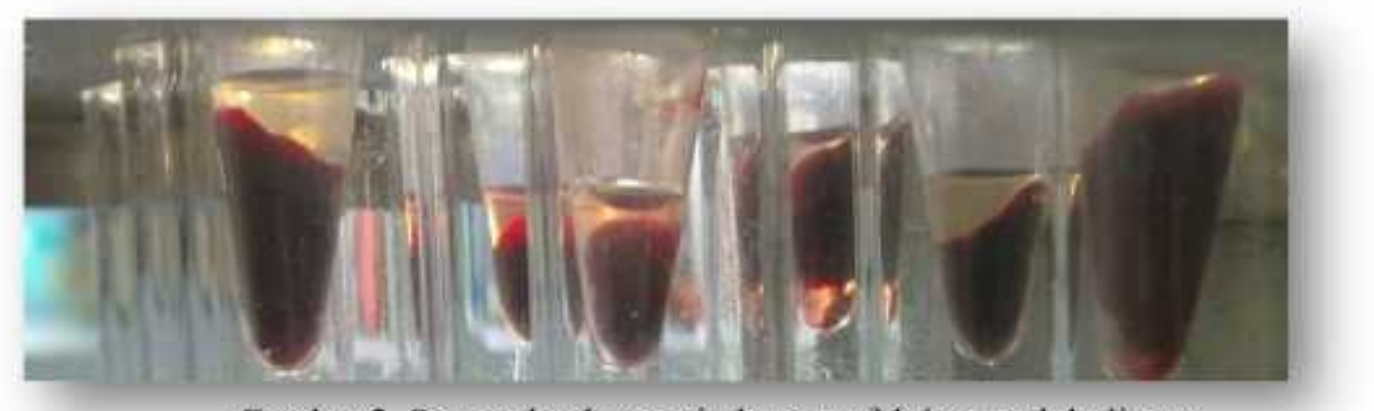

Gambar 2. Serum darah mencit dengan efek imunoglobulinnya.

\section{KESIMPULAN}

Berdasarkan hasil penelitian maka disimpulkan bahwa Isolat bakteri probiotik dari susu kerbau, dapat meningkatkan aktivitas imunoglobulin yang lebih pada hewan uji mencit sehingga dapat digunakan sebagai imunomodulator.

\section{DAFTAR PUSTAKA}

Çaglar, E., Kargul. B., \& Tanboga. I., 2005, Bacteriotherapy and Probiotics Role on Oral Health. Review Article Blackwell Munksgaard, 11. Pp. 131-136. 
Moller C, Vrese MD. Review :probiotics effects of selected acid bacteria,Institute for Physiology and Biochemistry of Nutrition. Federal Research Center for Nutrition and Food, Location Kiel, D24103 Kiel,Germany. 2004. pp 5-2

Safitri R., 2009, Manfaat Bakteri Probiotik untuk Kesehatan Manusia. Medical Review vol 22.FMIPA Universitas Pajajaran. Bandung.

Wiwi H., 2011, Pengaruh Bakteri Probiotik Dari Berbagai Sumber Terhadap Aktivitas Imunoglobulin M (IgM) Pada Mencit Jantan (Mus musculus). Skripsi. Fakultas Farmasi Universitas Hasanuddin. Makassar.

Dwyana, Z, 2009, Isolasi Bakteri Asam Laktat Dari Susu Kerbau dan Potensinya Sebagai Penghasil Antimikroba. Jurusan Biologi FMIPA Universitas Hasanuddin. 